\title{
Etnografia wielostanowiskowa: inspiracje metodologiczne do badań nad politycznością
}

\section{Multi-sited ethnography: methodological inspirations for research in political science}

Stowa kluczowe: etnografia wielostanowiskowa, polityka, polityczność, małe miasto, wiedza lokalna, mobilność

Keywords: multi-sited ethnography, politics, politicalness, small town, local knowledge, mobility

Abstrakt: Mobilność przestrzenna i społeczna $w$ przyspieszajacym globalnym świecie wiqże sie z nowymi wyzwaniami wobec nauk społecznych, $w$ tym politologii. Dotyczy to równiė metod $i$ metodologii. Artykuł zawiera próba pokazania potencjału poznawczego, który zawiera sie $w$ wykorzystaniu etnografii wielostanowiskowej (multi-sited ethnography) do badan nad polityka oraz badaniem polityczności (tego, co polityczne - das Politische). Użyteczność tego podejścia została zilustrowana $w$ oparciu o badania nad mobilnościa społeczna i przestrzenna mieszkańców małego miasta prowadzone przy wykorzystaniu tej metody.

Abstract: Spatial and social mobility in an increasingly globalized world is associated with new challenges for social sciences, including political science. This also applies to methods and methodology. The article aims to reveal the cognitive potential that lies in the use of

* ORCID ID: https://orcid.org/0000-0002-4870-3333, pracownik w Katedrze Socjologii Polityki i Marketingu Politycznego na Wydziale Nauk Politycznych i Studiów Międzynarodowych, członek Ośrodka Badań nad Migracjami Uniwersytetu Warszawskiego. Kierował krajowymi i międzynarodowymi projektami badawczymi. Obecnie prowadzi badania w ramach projektu NCN Mobilność społeczna i terytorialna $w$ doświadczeniu biograficznym i pokoleniowym mieszkańców matego miasta. E-mail: w.lukowski@uw.edu.pl 
multi-sited ethnography for research on politics and on the study of political behaviors (das Politische). The utility of this approach is illustrated on the basis of the research on social and spatial mobility of small town residents conducted with the use of this method.

\section{Wprowadzenie}

Motywem do napisania tego artykułu stały się badania prowadzone w latach 2017-2020 w ramach projektu Mobilność społeczna i przestrzenna $w$ doświadczeniu biograficznym i pokoleniowym mieszkańców małego miasta ${ }^{1}$. Projekt ten generował już na etapie konceptualizacji pytania o charakterze metodologicznym. Miały one zróżnicowany charakter od pytań bardziej fundamentalnych, czym jest mobilność po pytania bardziej szczegółowe jak dobierać osoby czy „stanowiska” do badań. W trakcie badań (podkreślam w ich trakcie, a nie na etapie projektowania) wysunięta została hipoteza, że mobilność można ujmować jako proces gospodarowania zasobami - ich pozyskiwania, tracenia i przede wszystkim utrzymywania. Stało się to ważne również z punktu widzenia powiązania tego z adekwatną metodologią.

Badania zostały zlokalizowane w małym mieście, za czym stała intencja prowadzenia badań właśnie w przestrzeni stosunkowo niewielkiej, ale jednocześnie mezzospołecznej: niewielkiej, zatem umożliwiającej bardziej „mikroskopowe” badanie istotnych zjawisk; mezzospołecznej - ulokowanej pomiędzy makrostrukturami społecznymi, a jednostkowym, rodzinnym czy sąsiedzkim wymiarem życia społecznego.

Jak się można było spodziewać okazało się, że małe miasto, chociaż „małe” jest niezwykle złożoną strukturą ekologiczną, w które toczy się rywalizacja o różnorakie zasoby, w tym o tak fundamentalne jak przestrzeń, czas czy uznanie społeczne. W tej rywalizacji biorą udział nie tylko mieszkańcy tego miasta, osoby aspirujące do pozycji w lokalnym samorządzie, ale równiėz "gracze” zewnętrzni - deweloperzy, rezydenci, turyści. W polskich realiach, ale nie tylko, istotnym „graczem” jest diaspora rozrzucona po całym świecie. W transnarodowej czy może ściślej translokalnej przestrzeni społecznej² miejsce pochodzenia pozo-

1 Territorial and social mobility in the biographical and generational experience of the inhabitants of a small town - analysis on the example of Gizycko (2017-2020) supported by a grant from the Polish Science Center, project number 2016/21/B/HS6/0387 OPUS 11.

2 We współczesnych badaniach nad migracjami międzynarodowymi dostrzega się wytwarzanie nowego rodzaju przestrzeni społecznej określanej jako przestrzeń transnarodowa, rzadziej jako przestrzeń translokalna. W obu przypadkach chodzi o uchwycenie nowego 
staje nie tylko ważnym miejscem sentymentalnych odniesień (miejscem szczęśliwego dzieciństwa, dumy z jego walorów architektonicznych czy przyrodniczych), ale również przestrzenią mniej lub bardziej pragmatycznych aktywności (zakup nieruchomości, remonty i modernizacje już posiadanych, opieka nad rodzicami czy dziadkami, intencjonalne przygotowywanie się do powrotu „na stare lata”, niezależnie od tego, czy on rzeczywiście nastąpi).

Dostrzegłem, że to co tutaj nazywamy politycznością daleko wykracza poza rywalizację polityczną sensu stricto - walkę o miejsce w radzie miasta, rywalizację o stanowisko burmistrza, a następnie starania o reelekcję. W sferze polityki i polityczności zlokalizowana jest rywalizacja o zasoby prowadzona przez aktorów, którzy nie aspirują do zajmowania funkcji w samorządzie lokalnym czy wojewódzkim, czy na szczeblu ogólnokrajowym (np. bycie posłem czy senatorem). Wywierają jednak istotny wpływ na pozycję aktorów stricte politycznych na przykład burmistrza miasta, uzyskują, utrzymują a czasem również tracą kontrolę nad takim czy innym zasobem czy wieloma zasobami (dopiero posiadanie kilku zasobów sprzyja ich skutecznemu utrzymywaniu).

Rozróżnienie między polityką a politycznością jest jednym z głównych rozróżnień we współczesnych naukach społecznych. Za pomocą pojęcia polityki koncentrujemy się na wyjaśnianiu ładu instytucjonalnego, państwowego zarządzania sprawami publicznymi. Zaś posługując się pojęciem polityczności podkreślamy znaczenie nie dających się uniknąć sytuacji konfliktu, sporów, nieciągłości, kryzysów itd.

Ten artykuł poświęcony jest metodologicznej propozycji badań nad politycznością. Nie dokonuję zatem bardziej szczegółowej prezentacji sposobów rozumienia tego pojęcia. Jednak nim przejdę do tego, jak sam rozumiem to pojęcie (w ścisłym powiązaniu $\mathrm{z}$ istniejącymi ujęciami) szkicowo zrelacjonuję najbardziej wpływowe ujęcia ${ }^{3}$.

Po pierwsze, polityczność to specyficzna sfera tego, co społeczne i w zasadzie synonim pojęcia polityki. To, co polityczne i to, co państwowe stanowi w tym ujęciu nierozłączną, wręcz tożsamą całość. Relacje między sferą polityczną a innymi sferami życia postrzegane są horyzontalnie

wymiaru ruchliwości skutkującego mniej lub bardziej równoważną obecnością mobilnych ludzi w dwóch czy więcej przestrzeniach - na przykład dwóch przestrzeniach krajowych, ale także często znacznie od siebie oddalonych przestrzeniach społeczności lokalnych.

3 Posługuję się przeglądem jej współczesnych ujęć, który uznaję za reprezentatywny: U. Bröckling, R. Feustel, Das Politische denken, [w:] U. Bröckling, R. Feustel (red.), Das Politische denken. Zeitgenossische Positionen, Bielefeld: Transit Verlag 2012, s. 7-19. 
- jako ich współistnienie albo wertykalnie jako podporządkowanie bądź zwierzchnictwo. Albo to co polityczne ujmowane jest jako jedna z wielu sfer aksjologicznych (Max Weber), albo jak w marksistowskiej ortodoksji jako nadbudowa determinowana przez bazę ekonomiczną (Karol Marks), czy jak u Carla Schmitta to, co polityczne jest terytorium wszystkich innych terytoriów. W tym ujęciu dokonuje się opisu różnych elementów państwa i ich relacji, bardziej współcześnie jest to analiza porównawcza systemów politycznych.

Po drugie, to, co polityczne ujmowane jest jako specyficzne okoliczności i uwarunkowania ludzkiego działania względnie komunikacji międzyludzkiej, czy wszelkie sposoby działania i komunikowania, które charakteryzują sferę polityki czy powinny ją charakteryzować. W tym ujęciu zawiera się Schmittowskie rozróżnienie wroga i przyjaciela, czy traktowania jako politycznej każdej formy bycia ludzi ze sobą, ich komunikacji, porozumienia i zgodnego działania jak u Hannah Arendt.

Po trzecie, ujmowanie polityczności ze względu na jej wymiar temporalny. Także tutaj można odnaleźć wykluczające się ujęcia, to nic innego tylko cierpliwe działanie jednocześnie z namiętnością i umiarem (Max Weber). Tutaj podkreślany jest aspekt ciągłości. Zaś Walter Benjamin rozpoznaje moment polityczny w rewolucyjnym przerwaniu historycznej ciąłości.

Po czwarte, pojęciu polityczności przypisuje się negatywnie bądź pozytywnie konotowany wymiar normatywny. To, co polityczne jest albo gwarancją albo przeciwieństwem moralnej orientacji. W ujęciu pozytywnym - w pewnym uproszczeniu - można powiedzieć, że polityka jest gwarancją bezpieczeństwa, wolności, sprawiedliwości czy pokoju, zaś w ujęcia negatywnym jest odwrotnie - polityka to sfera oddalająca nas od tych wartości bądź je negująca.

Wszystkie te ujęcia - tutaj niezwykle zdawkowo przedstawione, zachowują swoją ważność jako istotny kontekst teoretyczny w dalszych rozważaniach.

Z wpływowych koncepcji teoretycznych szczególne znaczenie przypisuję ujęciu Bruno Latoura - jego programowi ekologii politycznej zawierającemu rozszerzone rozumienie przestrzeni politycznej, włączenie do niej innych niż ludzie aktorów - roślin, zwierząt, przyrody nieorganicznej i artefaktów - włączenie ich do politycznej zbiorowości i danie im równoprawnego głosu w „parlamencie rzeczy” ${ }^{4}$. Latour twierdzi, że postulo-

4 B. Latour, Das Parlament der Dinge. Für eine politische Ökologie, Frankfurt nad Menem 2011. 
wana przez niego ekologia polityczna nie zaczęła jeszcze tak naprawdę istnieć. Polityka i ekologia miałby być jedynie dość nieporadnie zestawianymi ze sobą pojęciami. Pojęcia polityki i ekologii były przez stulecia tak określane, że żadne zbliżenie między nimi, żadna synteza nie była możliwa. Ważną wskazówką jest jednoczesne ujmowanie i analizowanie pojęcia logos, oikos, physis i polis w ich wzajemnym powiązaniu.

Inspiracja ta wymagałaby szerszego omówienia. Tutaj tylko zaznaczę, że ujmowanie sfery polityczności przede wszystkim jako ekologicznej czasoprzestrzeni oznacza dla mnie nie tylko rozszerzenie przestrzeni politycznej na całą przyrodę, oznacza również postrzeganie ludzi w kategoriach ekologicznych. Co to oznacza?

Przede wszystkim oznacza, że to, co polityczne to nic innego jak rywalizacja o zasoby, jak wysiłki na rzecz utrzymania zasobów, jak zajmowanie nisz ekologicznych zagrożonych przez "gatunki” inwazyjne czy mniej lub bardziej nie dające się przewidzieć zmiany środowiskowe, jak współzależność, jak przede wszystkim dążenia do adaptacji i zachowania równowagi.

Mało miasto jest przeze mnie ujmowane jako system ekologiczny, które tworzą ludzie ze zróżnicowanym doświadczeniem biograficznym, pokoleniowym, sąsiedzkim, rodzinnym, migracyjnym, aksjologicznym, obywatelskim itd. System ten wypełniają również inni „aktorzy”. W przypadku miasta, o którym tutaj jest mowa, a które położone jest w uznawanej za wyjątkowo atrakcyjną krainie wielkich jezior - są to jeziora i ich otoczenie. Ludzie wchodzą z nimi w wielorakie interakcje. Nie można jednak wykluczyć, że ta relacja jest zwrotna - to jeziora często poddawane bezwzględnej antropopresji „komunikują się” z ludźmi, chociażby poprzez przyspieszające procesy eutrofizacji ${ }^{5}$ czy wytwarzanie toksycznych sinic.

\section{Etnografia wielostanowiskowa a badania nad tym, co polityczne (nad politycznością)}

Etnografia wielostanowiskowa postrzegana jest jako reakcja na przemiany współczesnego świata, jego globalizację, zwiększająca się mobilność ludzi, idei, towarów, usług. Konsekwencją tych przemian - tak widział

5 Proces wzbogacania zbiorników wodnych w pierwiastki biofilne, skutkujący wzrostem trofii, czyli żyzności wód. Proces ten dotyczy nie tylko zbiorników wodnych, ale również cieków. 
to George Marcus - była właśnie taka próba przeformułowania sposobu prowadzenia badań etnograficznych, w które te badania prowadzone są w wielu miejscach i opierają się na podążaniu za aktorami zdarzeń ${ }^{6}$. Trudno byłoby przy tym jednoznacznie stwierdzić, czy to podejście pozostaje w wyraźnej opozycji do tradycyjnie rozumianych badań terenowych, jednak na pewno jest próbą przezwyciężenia jego ograniczeń. W klasycznym ujęciu „teren” definiowany jest statycznie, ściśle określony jest on zarówno czasowo, przestrzennie, jak i problemowo. W tym podejściu zaś „stanowiska” mogą być ulokowane bez żadnych ograniczeń czasowych i przestrzennych. Oznacza to że, gdy prowadzimy badania w małym mieście czy nad małym miastem, dane stanowisko może być oddalone od niego o tysiące kilometrów, gdy rozmawiamy (najczęściej za pośrednictwem Internetu) z osobami, które z tego miasta wyemigrowały. Może się też zdarzyć, że w bardzo odległej przeszłości dawni mieszkańcy czy ówczesne władze podjęły decyzje, które obecnie nadal silnie oddziałują na to miasto.

Także w zbliżonym pojęciu assamblage $e^{7}$ zawarta jest intencja, że moga tworzyć go nie tylko stanowiska zróżnicowane przestrzennie i czasowo, ale również być ulokowane w różnych sferach życia, dziedzinach. Pożądane staje się równoprawne traktowanie źródeł „fizycznych” i internetowych i to we wzajemnych powiązaniu. Można zauważyć, że rzeczywistość fizyczna zaczyna działać, być tworzona zgodnie z logiką „linkowania”, właściwą dla rzeczywistości ulokowanej w przestrzeni wirtualnej. Te dwie „rzeczywistości” przecinają się wzajemnie, sprzęgają w taki sposób, że uprawnione jest mówienie o jednej, złożonej rzeczywistości.

Badacz wraz z postępującą globalizacją znajduje się coraz bardziej w gąszczu/gęstwinie globalizującego się świata. Konfrontowany jest także z wieloma kontekstami równocześnie, które stwarzają trudności nie tylko $\mathrm{w}$ fazie eksploracji, ale również $\mathrm{w}$ fazie interpretacji pozyskanych danych czy pisania tekstów.

Wielostanowiskowe badania etnograficzne (można też mówić o takim podejściu w odniesieniu do badań o nachyleniu socjologicznym i antropologicznym czy politologicznym) stanowią próbę dokonania użytecznej zmiany metodologicznej wymuszanej przez przemiany społeczne, w tym coraz większą skłonność do mobilności jako intencjonalnie postrzeganej,

6 G. Marcus, Ethnography through Thick and Thin, Princeton 1998.

7 S. Hess, M. Schwertl, Vom „Feld“ zum „Assemblage“? Perspektiven europäisch-ethnologischer Methodenentwicklung - eine Hinleitung, [w:] S. Hess, J. Moser, M. Schwert (red.), Perspektiven etnhologisches Forschen, Neue Methoden und Konzepte, Berlin 2013, s. 13-38. 
skutecznej formy radzenia sobie w życiu. Takie propozycje jak transnarodowa czy translokalna przestrzeń społeczna są próbą wskazania na to, że także o mieście nie da się dziś adekwatnie mówić jako o tworze, które by nie był współtworzony nie tylko przez jego mieszkańców, ale również turystów, rezydentów, diasporę i wielu innych aktorów.

Badacz prowadzacy badania w duchu etnografii wielostanowiskowej może być porównany z podróżnikiem, i to może takim, na jakiego zwrócił uwage Claude Lévi Strauss w Smutku tropików ${ }^{8}$. Próbując ująć sens swoich wypraw do Brazylii, Stanów Zjednoczonych czy Indii pisał, że każda podróż jest czymś więcej niż poruszaniem się w przestrzeni: jest to również podróż w czasie i w hierarchii społecznej. Każde wrażenie związane z podróżowaniem może być tylko wtedy w pełni określone, gdy odniesie się je do tych trzech osi, a ponieważ sama przestrzeń ma trzy wymiary, to trzeba co najmniej pięciu wymiarów, aby uzyskać adekwatny obraz danej podróży.

Wskazał w tym ujęciu na relacyjny wymiar przestrzeni społecznej. Poczynione założenia odnośnie zajmowanej pozycji, odnośnie tego kim jesteśmy, są relatywizowane przez konfrontację z innymi, często bardzo odmiennymi warunkami. Wtedy możemy dostrzec, że nasza pozycja wcale nie jest taka stabilna i oczywista jak sądziliśmy.

Przywołuję Lévi Straussa, aby pokazać, że wtedy, gdy mówię o „podróżowaniu” między wieloma stanowiskami konfrontuję się z wielowymiarowością życia społecznego. Przemieszczanie to relatywizuje pozycję badacza, w pewnym sensie może on spojrzeć na siebie jako na jeszcze jedno „stanowisko”. Nawet jeśli byśmy uznali ten pogląd za zbyt radykalny, to z pewnością badacz traci uprzywilejowaną pozycję - on bada, a inni są badani.

Badając miasto, które określam jako miasto małe ${ }^{9}$, dzięki wielu stanowiskom bardziej dostępne poznawczo staje się jego miejsce w przestrzeni społecznej globalizującego się świata. Uzyskuję poznawczy dostęp do jego specyfiki czy tė̇ cech.

Podmiotowość małych miast postrzegana jest przez pryzmat dwóch waloryzujących je schematów. Pierwszy z nich polega na tworzeniu osi małe miasta - średnie miasta - duże miasta - metropolie (lub bardziej ogólnie: małe miasto versus duże miasto). Takie definiowanie prowadzi

8 C. Levi-Strauss, Smutek Tropików, tłum. Aniela Steinsberg, Warszawa 1964.

9 W klasyfikacji miast w Polsce za miasta małe uznaje się miasto do 20 tysięcy mieszkańców. Z socjologicznego i antropologicznego punktu widzenia za takie miasta uznajemy również miasta o większej liczbie mieszkańców. W tym przypadku jest to miasto liczące ok. 28 tysięcy mieszkańców. 
do porównań, które stawiają małe miasta na „przegranej pozycji”, bo wielu elementów, które tworzą tkankę wielkie miasta tutaj nie będzie, a inne mogą stanowić jedynie próbę imitacji. I tak w małym mieście nie będzie teatru czy filharmonii, ale - jak w mieście moich badań - będzie nowoczesna sala koncertowa przy szkole muzycznej; nie będzie szkoły wyższej, ale będzie filia prywatnej szkoły wyższej; nie będzie wegańskich restauracji, ale będą restauracje oferujące kuchnię fusion; nie będzie wielkiego centrum handlowego czy galerii, ale obiekty znacznie mniejsze; nie będzie dużego kina czy multipleksu, ale niewielkie kino czynne w weekendy; nie będzie basenu z licznymi atrakcjami, ale będzie jego pomniejszona wersja. Zdarzyć się może - jak to ma miejsce tutaj - że istnieje coś, co posiadają tylko duże miasta, a mianowicie pełnowymiarowe kryte lodowisko ${ }^{10}$.

Drugi schemat waloryzujący małe miasta sprowadza się do poszukiwania i eksponowania ich wyjątkowości czy niepowtarzalności. Wykorzystuje się do tego istniejące zasoby, jak również kreuje się nowe. Wpisuje się to w praktykę traktowania kultury jako „pojemnika” z zasobami, po które można dowolnie sięgać, aby podnieść jakość życia i zdolność do konkurencji11.

$\mathrm{Z}$ pomocą przychodzi często lokalna historia: ważne wydarzenia z przeszłości, najlepiej takie, która miały możliwie jak najbardziej ponadlokalny zasięg, położenie przyrodnicze postrzegane jako atrakcyjne czy wymyślanie tradycji ${ }^{12}$, ale również „wymyślanie” teraźniejszości oraz przyszłości. To wymyślanie czy wynalezienie wyjątkowej przeszłości i wyjątkowej teraźniejszości oraz wyjątkowej przyszłości dokonuje się na przykład poprzez przekształcanie legend w mity założycielskie czy czynienie małego miasta „stolicą kraju”: na przykład stolicą żeglarską, rowerową czy wojskową Polski ${ }^{13}$.

10 Miasto w latach 60. i 70. XX wieku było miejscem masowego uprawiania łyżwiarstwa szybkiego przez młodzież szkolną, co przekładało się na sukcesy odnoszone na zawodach w kraju i zagranicą. Najlepsi trafiali do kadry narodowej. Wówczas w mieście nie było sztucznego lodowiska czy toru łyżwiarskiego, ale warunki klimatyczne sprzyjały uprawianiu łyżwiarstwa przez całą zimę. Ta legenda miasta jako „łyżwiarskiego mocarstwa”, miasta pod tym względem nieporównywalnego z innymi małymi miastami w Polsce wpłynęła na poczucie wyjątkowości. I była głównym impulsem do budowy sztucznego, krytego lodowiska.

11 A. Reckwitz, Die Gesellschaft der Singularitäten, Frankfurt nad Menem 2016.

12 E. Hobsbawm, T. Ranger (red.), Tradycja wynaleziona, Kraków 2008.

13 W tym artykule analizujemy miasto, które władze nazwały „Żeglarską Stolicą Polski”. Sąsiednie miasto jest ze względu na przebiegającą przez nie słynną trasę „Rowerową stolicą Polski”. Również pobliski miasteczko ze względu na stacjonujące w nim wojsko 
Rytm życia miasta, o którym tutaj jest mowa, wyznacza podział na dwumiesięczny letni sezon turystyczny i pozostałą część roku. Latem miasto nie tylko zapełnia się turystami, ale również w tym okresie odbywa się zdecydowana większość imprez kulturalnych, rozrywkowych, zawodów sportowych (przede wszystkim regaty żeglarskie). Turystyka traktowana jest przez władze miasta i wielu mieszkańców jako najważniejsza gałą́ lokalnej gospodarki. W mieście istnieje kilka średniej wielkości zakładów przemysłowych (m.in. spółdzielnia mleczarska, fabryka kotłów). Za drugą kluczową dla funkcjonowania miasta sferę uznaje się istnienie w nim dużego garnizonu wojskowego.

W wielu małych miastach, również tych, w których potencjał wyjątkowości jest znaczny, istnieją zróżnicowane, naznaczone pokoleniowo i środowiskowo „definicje” miasta. Określenie „definicje” opatruję cudzysłowem, bowiem daje się je wywieść jedynie z często rozproszonych wypowiedzi formułowanych przy różnych okazjach - w trakcie kampanii wyborczych, na łamach lokalnej gazety, konferencjach prasowych (wypowiedzi burmistrza miasta), posiedzeniach rady miasta czy w mediach społecznościowych. Możliwe jest też ich rekonstruowanie w oparciu o podejmowane działania.

Jak dobierać lokalizacje stanowisk badawczych? Jak uniknąć ich przypadkowości? Jak ograniczać ich liczbę, jak konstruować próbki do badań? Jak dzięki tym stanowiskom „zawieszać” skłonność do wtłaczania obserwowanych zjawisk w dostępne kategorie, czyli zapewniać przewagę procedur indukcyjnych nad dedukcją? Jak wiązać ze sobą obserwacje i analizę zróżnicowanych źródeł?

Są to pytania, które w zasadzie stale towarzyszą procesowi badawczemu niezależnie od metody. Mają one tutaj swoją specyfikę - jest nią charakter obecności badacza w badanej czasoprzestrzeni - obecność ta nie jest okazjonalna czy ściśle ulokowana na osi - podmiot badający - przedmiot badania. Ważnym postulatem jest współpraca (collaboration) ${ }^{14}$, którą rozumiem nie tyle jako funkcją doradcza, dostarczanie aktorom wiedzy, ale raczej jako wzajemny przepływ inspiracji, refleksji, pytań czy odpowiedzi, jako tworzenie się więzi między badającymi a badanymi, które będą wykraczały poza ograniczony czas prowadzenia badań. Badacze uzyskują dzięki temu możliwość śledzenia procesów czy zjawisk, czy po prostu

i jeden z największych poligonów wojskowych zostało nazwane „Wojskową Stolicą Polski”.

14 Por. np. Matsutake Worlds Research Group Strong Collaboration as a Method for Multi-sited Ethnography: On Mycorrhizal Relations, [w:] M.A. Falzon (red.), Multi-sited Ethnography. Theory, Praxis and Locality in Contemporary Research, Routledge 2009, s. 197-214. 
dalszych losów osób, które były przez nich badane. Dzieje się to już poprzez śledzenie profili na portalach społecznościowych. Dzięki nim możliwe jest nawiązanie w każdej niemal chwili kontaktu z tymi osobami.

Tworzenie stanowisk jest procesem rozciągniętym w czasie. Na etapie projektowania badań lokalizowane są stanowiska wyjściowe. W przypadku badań, na które tutaj się powołuję tymi stanowiskami były szkoły ponadpodstawowe i ponadgimnazjalne w małym mieście i ich absolwenci. Założyłem, że uda się śledzić ich losy życiowe na przestrzeni co najmniej czterdziestu lat - od połowy lat 70. XX wieku do połowy pierwszej dekady XXI wieku, dobierając osoby do badań w dziesięcioletnich odstępach, licząc od daty ukończenia szkoły. Wywiady biograficzne miały zostać uzupełnione rozmowami z ekspertami lokalnymi i analizą danych zawartych w różnych źródłach (prasa lokalna, protokoły rady miasta, strategie rozwoju itd.).

Można zatem powiedzieć, że projekt badań był w punkcie wyjścia zakrojony tak, że będą to klasyczne badania terenowe, w których nie będziemy wychodzić poza jasno zakreślone ramy przedmiotowe i czasowe. Wielostanowiskowość była dopiero wynikiem decyzji podejmowanych w trakcie badań. Na przykład rozmowa biograficzna z osobą przeprowadzona za pomocą komunikatora internetowego, która z małego miasta wyjechała do Stanów Zjednoczonych, została uzupełniona analizą jej aktywności na portalu społecznościowym.

W trakcie badań ujawniła się również wyróżniająca się aktywność dwóch środowisk wyraźnie określonych pokoleniowo - trzydziestolatków na przełomie lat 80. i 90. XX wieku oraz środowiska w podobnym wieku na przełomie pierwszej i drugiej dekady XXI wieku. Oba te środowiska skierowały swoją aktywność na sprawy lokalne i regionalne, zakładając stowarzyszenia. Pierwsze z nich skupiło się na odkrywaniu i pielęgnowaniu bogatego dziedzictwa kulturowego regionu i kwestiach ekologicznych, drugie zaś skupiło się bardziej na próbach uczynienia miasta atrakcyjnym również dla jego młodych i młodszych mieszkańców i w ten sposób zahamowania migracji.

W trakcie badań krystalizowały się również stanowiska teoretyczne. $\mathrm{W}$ założeniach teoretycznych centralne miejsce zostało przypisane teorii dualnego rynku pracy ${ }^{15}$ czy warszawskiej szkole badań nad ruchliwością społeczną ${ }^{16}$. W trakcie badań ujawniła się użyteczność teoretyczna

15 M.L. Piore, Birds of Passage: Migrant Labor and Industrial Societies, Cambrigde 1979.

16 W. Wesołowski, K. Janicka, K. Słomczyński, Strukturalizacja społeczeństwa polskiego. Ewolucja paradygmatu, Warszawa 2017. 
takich ujęć jak teoria utrzymywania zasobów Stevana Hobfolla ${ }^{17}$, koncepcja kapitalizmu kulturowego Andreasa Reckwitza ${ }^{18}$, ujęcia ekologiczne jak na przykład panarchia czy ciągle nośna teoria Pierre'a Bourdieu ${ }^{19}$. „Pojawianie się” tych teorii wiązało się z rozszerzaniem się kontekstu teoretycznego i było powiązane $\mathrm{z}$ odkrywaniem, w indukcyjnie analizowanych biografiach, określonych prawidłowości. Na przykład okazywało się, że wtedy, gdy materiał biograficzny umożliwiał analizę przekazu międzypokoleniowego, istotne okazywało się nie tyle pozyskiwanie nowych zasobów, ale utrzymywanie kluczowych zasobów - stąd znaczenie teorii Hobfolla. Okazała się ona istotnym wsparciem, gdy przyjęliśmy hipotezę, że mobilność może być ujmowana jako gospodarowanie zasobami.

Znaczenie uzyskały również stanowiska, które określiliśmy jako „przypadkowe”, jak przypadkowe spotkania z mieszkańcami w sklepach, konflikty lokalne i wiele innych. Dostarczały one często jedynie ograniczonych, ale też dających wgląd w mechanizmy funkcjonowania małego miasta informacji.

Przypomnę, że badanie tego, co polityczne nie było moim głównym zamiarem. Wymiar ten ujawnił się jako poboczny skutek prowadzenia etnograficznych badań wielostanowiskowych. To jest istotna zaleta tej procedury, że otwiera nas ona na inne wymiary badanej rzeczywistości. $\mathrm{Z}$ pewnego punktu widzenia jest i wada, bowiem może utrudniać koncentrację na tym, co stanowi rdzeń naszych poszukiwań, w tym przypadku jest to mobilność społeczna i przestrzenna mieszkańców małego miasta. Koncentracja ta jest i pozostanie kwestią godzenia autodyscypliny z ciekawością badawczac.

Przytoczę zatem dwa przykłady, w których ujawnił się polityczny wymiar rzeczywistości w przyjętym powyżej rozumieniu.

\section{Definicje miasta, wiedza lokalna a to, co polityczne}

Wspomniałem już, że różni aktorzy różnie definiują miasto - to oczywiste. W przypadku małego miasta - o czym już pisałem powyżej - definicje te oscylują między porównaniami z dużymi miastami a podkreślaniem lokalnej specyfiki i atrakcyjności. Wpisują się również

17 S.E. Hobfoll, Stres, kultura i społeczność. Psychologia i filozofia stresu, Gdańsk 2006.

18 P. Bourdieu, L.J.D. Wacquant, Zaproszenie do socjologii refleksyjnej, Warszawa 2001.

19 L.H. Gunderson, C.S. Holing, Panarchy. Understanding transformations in human and natural systems, Washington, Corelo, London 2002; P. Bourdieu, L.J.D. Wacquant, Zaproszenie do... 
w to, co Clifford Geertz nazwał wiedzą lokalną ${ }^{20}$. Geertz rozumiał ją przede wszystkim jako spojrzenie na daną kulturę poprzez pryzmat jej wewnętrznych schematów. Antropologia interpretatywna zakłada wejście w dialog z opisywaną kulturą, znalezienie klucza do jej jak najwierniejszego tłumaczenia na realia naszej własnej kultury. To „budowanie mostów” wymaga dogłębnego poznania właściwego dla lokalnej kultury świata symboli i zależności między nimi - by zrozumieć dany komunikat nie należy jedynie poprzestać na jego opisaniu, trzeba również przedstawić jak najszerszy kontekst. Opis taki Geertz nazwał „gęstym”.

O ile jednak Geertzowi chodziło o jedna czy dominującą wiedzę lokalną, która zakłada pewien wspólny wewnętrzny rdzeń interpretacyjny dla jej członków, o tyle tutaj chodzi o kilka interpretacji, czym jest miasto, jakie ma cechy, a jakie powinno mieć. Należy też podkreślić, że wiedza lokalna jest czymś, co przyjmowane jest bezrefleksyjnie jako rodzaj oczywistości. Ich zróżnicowana treść może odzwierciedlać zróżnicowane doświadczenia pokoleniowe i środowiskowe. Interpretacje te są powiązane z rywalizacją o uznanie społeczne, z demonstrowaniem statusu społecznego w lokalnym świecie, w którym trudno czytelne są podziały i hierarchie społeczne. I być może te „definicje” i interpretacje w największym stopniu można odczytywać jako próby zniesienia czy wręcz unieważnienia tego, że małe miasto jest przede wszystkim - małym miastem, a więc również przestrzenią ograniczonych szans życiowych, w której podstawowe dylematy nie polegają na tym, co w tym mieście można robić, w czym się życiowo realizować, tylko czy zostać w nim, czy z niego wyjechać - bowiem atrakcyjne cele życiowe i środki do ich realizacji ulokowane są poza nim.

Miasto, w tym małe miasto, co prawda nie „podróżuje” w przestrzeni geograficznej, jednak chociażby przez postrzeganą atrakcyjność turystyczną czy inwestycyjną (spadającą lub rosnącą), rentę położenia (np. zwiększająca się przez zbudowanie w pobliżu drogi szybkiego ruchu) „przesuwa się” w przestrzeni społecznej. I to „przesuwanie się” lub również jego brak i proponowane sposoby na to, aby się ono dokonało jest przedmiotem proponowanych interpretacji. Za ich pomocą aktorzy rywalizują ze sobą o pozycje w mieście, próbują pozyskać dla siebie poparcie i uznanie społeczne.

Prowadzi nas to do hipotezy, że cechą (właściwością) miasta jest jego „mobilność”. Możemy tę mobilność postrzegać podobnie jak postrzegamy mobilność nie tylko jednostek, ale całych grup społecznych, w tym

20 C. Geertz, Interpretacje kultur, Kraków 2005. 
klas społecznych ${ }^{21}$. Uprawnione i poznawczo istotne jest dostrzeganie nie tyle mobilności mieszkańców miasta, co mobilności samego miasta rozumianego nie tylko jako społeczność, ale szerzej jako twór w taki czy inny sposób waloryzowany, posiadający atrakcyjność, mierzoną dumą z niego, satysfakcją zamieszkiwania w nim, porównaniami z innymi miastami itp.

W pisuje się to w relacyjne ujmowanie przestrzeni społecznej, w której jest ona widziana jako relacyjna sieć powiązań pomiędzy wypełniającymi ją bytami społecznymi (jednostki, grupy, stowarzyszenia, sąsiedztwa, partie polityczne, firmy etc.), a nie absolutystycznie jako rodzaj pustego pojemnika. Będzie to miało swoje odbicie również w interpretacjach tej przestrzeni. I trzeba podkreślić, że miasto chociaż nadal pozostaje jednym bytem fizycznym, to w interpretacjach takie już nie jest. Istnieje (co najmniej) kilka wyobrażonych przestrzeni. Te wyobrażenia nie muszą być całkowicie rozłączne, mogą być komplementarne, uzupełniające się, ale też wykluczające się, czy też zdefiniowane konfliktowo wzajemnie wobec siebie i stanowić podstawę rywalizacji politycznej.

Bliski jest mi sposób postrzegania przestrzeni przez Pierre'a Bourdieu. Definiuje on konstrukcje symboliczne jako społeczne działania, które są dokonywane ze względu na aspekt maksymalizacji użyteczności. Proponuje ujęcie lokujące w centrum działania społeczne, w których praktyki symboliczne są traktowane podobnie jak praktyki ekonomiczne: jako strategie w rywalizacji o miejsce w przestrzeni społecznej22. Przestrzeń społeczna jest zatem przestrzenią relacji. Określa ona układ grup osób na bazie takich samych albo zróżnicowanych możliwości dysponowania kapitałem ekonomicznym, społecznym czy kulturowym, który się uwidacznia w podobnych i zróżnicowanych habitusach.

Relacyjna przestrzeń społeczna jest mobilna i zmienia się pod wpływem takich czynników, jak rozwój technologiczny, przemiany ustrojowe i gospodarcze, zmiany społeczne. Nie wchodzę tutaj w szczegółowe rozważania jak można rozumieć „pokolenie”. W badanym mieście na przestrzeni lat od początku lat 90 . XX wieku wyraźnie swoją obecność zaznaczyły dwa środowiska wyróżnione przez przynależność do określo-

21 Przywołać należy efekt windy dostrzeżony przez Ulricha Becka odniesiony do przesuwania się w strukturze społecznej wielkich grup (U. Beck, Społeczeństwo ryzyka, Warszawa 2002) w drodze do innej rzeczywistości oraz efekt paternoster odkryty przez Andreasa Reckwitza (P. Bourdieu, L.J.D. Wacquant, Zaproszenie do socjologii refleksyjnej, Warszawa 2001) odniesiony do sytuacji, w której przesuwanie się „w górę” jednej grupy społecznej wiąże się z jednoczesną degradacją innej.

22 P. Bourdieu, L.J.D. Wacquant, Zaproszenie do socjologii refleksyjnej, Warszawa 2001. 
nej grupy wiekowej - na początku lat 90 . XX w. była to grupa ówczesnych trzydziestolatków, która założyła stowarzyszenie podkreślające znaczenie więzi regionalnych, w zróżnicowanym etnicznie i kulturowo regionie. Właśnie region i miasto uznane $\mathrm{w}$ nim za istotne $\mathrm{z}$ racji położenia i potencjału miało opierać swój rozwój w demokratycznej, wolnej Polsce i jednoczącej się Europie na poczuciu regionalnej i lokalnej tożsamości - odwoływano się do złożonej historii regionu wplecionej w dzieje Polski i Niemiec, przywiązywano wage do troski o środowisko naturalne, próbowano konfrontować zagraniczne doświadczenia w rozwoju turystyki z tym, czego oczekiwano tutaj. Stowarzyszenie to angażowało się na lokalnej scenie politycznej, wprowadzając do rady miasta swoich kandydatów oraz poprzez akcje społeczne, konferencje, seminaria, petycje próbowało wywierać wpływ na kierunek dokonujących się zmian w duchu swojego programu.

Podobna sytuacja zaistniała w mieście na przełomie pierwszej i drugiej dekady XXI wieku, gdy również ówcześni młodzi mieszkańcy - dwudziesto- i trzydziestoletni założyli stowarzyszenie stawiające na lokalną aktywność, szczególnie młodych mieszkańców. Jednym z postulatów było zapewnienie miastu takiego rozwoju, który by powstrzymał wyjazdy z niego. Stowarzyszenie i osoby z nim związane powiększają stan posiadania w radzie miasta (obecnie w 2020 r. mają w radzie sześciu na dwudziestu jeden radnych).

Można powiedzieć, że te dwie reprezentacje społeczne nie tylko zresztą młodego pokolenia, bo ich postulaty i aktywność przemawiała i przemawia do mieszkańców w różnym wieku „rozminęły się” w czasie. Wskazuje to między innymi na to, że w niewielkim mieście, inaczej niż w większych miejscowościach, w rywalizacji politycznej, dokonującej się na szczeblu krajowym może „brakować” jakiegoś podmiotu czy też wystarcza zasobów społecznych na uformowanie się tylko jednej reprezentacji. I tak „Wspólnotowcy” z początku lat 90. XX wieku byli zorientowani lewicowo-liberalnie, co odpowiadało dominującym siłom na ówczesnej polskiej scenie politycznej. „Aktywni” zaś mają poglądy konserwatywno-prawicowe i związani są z obecnie dominującą partią.

W kontekście rozważań nad wielostanowiskową etnografią przywołałem ten przykład, aby zwrócić uwagę na to, że właśnie dzięki takiemu podejściu, zróżnicowanie pokoleniowe nie jest postrzegane przez pryzmat obecnych w literaturze sposobów rozumienia pokolenia ${ }^{23}$ (stanowią

23 Np. P. Szukalski, Solidarność pokoleń. Dylematy relacji międzypokoleniowych, Łódź 2012. 
one punkt odniesienia), ale jest wywiedzione z obserwacji, prowadzonych rozmów, analizy wyników wyborów.

Przywołam główny wniosek, który nasuwa się w odniesieniu do - jak można by to nazwać - pokoleniowo zdeterminowanej artykulacji interesów i wartości związanych z mieszkaniem w małym mieście położonym w regionie uznawanym za atrakcyjny ze względu na zasoby przyrodnicze i kulturowe.

$\mathrm{Na}$ przestrzeni ostatnich trzydziestu lat od przełomu lat 80. i 90. XX wieku dwukrotnie doszło do artykulacji interesów i wartości przez formację wyraźnie określoną pokoleniowo. Odbyło się to w czasowym przesunięciu około 25-30 lat. Nie doszło zatem do bezpośredniej rywalizacji między dwoma środowiskami społecznymi, które mogłyby artykułować swoje interesy w rywalizacji, co widzimy na poziomie ogólnopolskim czy poziomach regionalnych w całym czasie trwania polskich przemian.

Srodowisko „Wspólnotowców” uzyskało w wyborach z 1994 r. większość w miejskiej radzie, zaś środowisko „Aktywnych” zwiększyło w ostatnich dwóch elekcjach (2014 i 2018) dwukrotnie swój stan posiadania. Wyzwaniem wtedy i obecnie pozostawał balans między reprezentacją lokalnych czy regionalnych interesów, a tworzeniem powiązań z działającymi w Polsce partiami politycznymi. Relacje z lokalną społecznością, poczucie, że reprezentuje się jej interesy wchodziło i wchodzi w kolizję z upartyjnieniem postrzeganym jako rodzaj wyobcowania i niepotrzebnego przenoszenia na poziom lokalny ogólnopolskich konfliktów i podziałów. Zarówno w przypadku pierwszego jak i drugiego pokolenia przeważało przekonanie, że sprawy lokalne mają przewagę nad identyfikacją partyjną.

Obserwacja lokalnej sceny politycznej, co najmniej od wyborów samorządowych jesienią 2014 r., gdy stanowisko objął obecny burmistrz wskazuje, że w przestrzeni debaty o sprawach miejskich możliwe jest wyodrębnienie co najmniej trzech definicji miasta obecnych w przestrzeni publicznej.

Najbardziej widoczna jest definicja proponowana przez urzędującego burmistrza. Można powiedzieć, że przejawia się ona nie tylko w deklaracjach programowych, kampanii wyborczej, ale w codziennym działaniu, gdy zapadają konkretne decyzje mające wpływ na życie mieszkańców. Być może ta codzienna praktyka przesuwa punkt ciężkości z formułowania bardziej refleksyjnych, programowych wypowiedzi w stronę informowania mieszkańców o podjętych decyzjach i znacznie częściej o sukcesach niż o porażkach.

Obecny burmistrz doszedł do władzy między innymi na fali ostrej krytyki poprzedniego burmistrza, który był nim przez trzy kadencje. 
Był wtedy radnym, prowadził swoją stronę internetową, udzielał się na lokalnym forum internetowym. Gdy pełni funkcję burmistrza jest burmistrzem bardzo widocznym w przestrzeni publicznej. W pełni wykorzystuje Internet. Angażuje się w inicjatywy społeczne, wspiera akcje charytatywne. Szczególnie wspiera lokalny sport. Podkreśla w swoich wypowiedziach potencjał miasta, który widzi głównie w położeniu w krainie jezior. W obietnicach wyborczych koncentrował się na tworzeniu nowych miejsc prac, zwiększaniu liczby mieszkań. Priorytetami są również komunikacja, infrastruktura miejska, a także sport ${ }^{24}$.

Widzi miasto w dwóch wymiarach jako swoiste centrum świata, co najmniej „stolicę” kraju, w tym przypadku stolicę wodną czy żeglarską. Drugim wymiarem, chociaż mniej widocznym jest ujmowanie miasta w porównaniu z innymi miastami.

W oczach burmistrza jego miasto jest wyjątkowe. Odróżnia to je zatem od zdecydowanej większości małych miast, które, chociaż nieuchronnie posiadają swój indywidualny charakter, to trudno jest je postrzegać jako szczególnie interesujące ${ }^{25}$.

To jest skrawek ladu, otoczony woda, przecięty trzema kanałami. Na tym skrawku ladu mieszka trzydzieści tysięcy ludzi, jest jeden $z$ większych garnizonów $w$ Polsce, jeden $z$ siedmiu ośrodków przygotowań olimpijskich, jedno z dwóch krytych lodowisk w województwie. Jest czyste powietrze, czysta woda $i$ dużo stońca i my tam mieszkamy ${ }^{26}$.

Wyjątkowość miasta, to zdaniem burmistrza jego położenie i zasoby przyrodnicze, ale też dostępność do obiektów, które zazwyczaj nie są utożsamiane z małymi miastami, np. kryte lodowisko czy kino.

Zwraca uwage na aktywność mieszkańców. Podkreśla, że miasto to ludzie i to w nich dostrzega wartość. W jednym z wpisów na blogu stwierdza, że w jego mieście mieszkają najbardziej kreatywni ludzie na świecie ( $X$ is home to the most creative people in the world! ${ }^{27}$ ) po czym wymienia młodych, giżyckich sportowców z najliczniejszymi osiągnięciami. Na jego profilu FB ostatnio można było znaleźć informacje o osiągnięciach osób pochodzących z miasta. Wyjątkowość miasta ujawnia się

$24 \mathrm{Na}$ podstawie wypowiedzi burmistrza na profilu facebook: burmistrziwaszkiewicz.pl (7.04.2021).

25 K. Heffner, z Uniwersytetu Ekonomicznego w Katowicach, podczas wykładu „Czy jest przyszłość dla małych miast w Polsce?”, Uniwersytet Warszawski, 7.11.19 r. Również K. Heffner, T. Marszał. Małe miasta - studium przypadków, Łódź 2005.

$26 \mathrm{Na}$ podstawie wypowiedzi burmistrza na profilu facebook: burmistrziwaszkiewicz.pl (7.04.2021).

$27 \mathrm{Na}$ podstawie wypowiedzi burmistrza na profilu facebook: burmistrziwaszkiewicz.pl (7.04.2021). 
w wyjątkowości ludzi. Come visit Giżycko to meet its exceptional people and discover the secrets of a picturesque town at the heart of the Great Masurian Lake Distric - pisze burmistrz na swojej stronie.

Niezwykłość miasta można wyraźniej dostrzec po zestawieniu z innymi miejscami na mapie Polski, czy świata. Miasto jest wyjątkowe samo w sobie, ale dodatkową (większą?) wyjątkowość można zauważyć, kiedy porównamy je z innymi miastami, czy regionami.

Mamy tu raj na ziemi. Miasto na tyle małe i nie na tyle duże, ze możemy poruszać się wszędzie pieszo. Nie musimy nigdzie się spieszyć, dojazdy nie kradna nam czasu tak, jak $w$ dużych miastach. Korków w zasadzie nie mamy. Mamy tu dostęp do zdrowego życia w każdej chwili. Pomyślimy po potudniu, że mamy ochote pójść na rower do lasu albo nad jezioro możemy, to zrobić. (...) Inni, ze Ślaska musza do nas jechać sześćset kilometrów i sq nie u siebie, a u kogoś. My to mamy na co dzieñ28.

Burmistrz porównuje miasto i jego mieszkańców do organizmu:

Miasto składa się z wielu obszarów. Wszystkie musza się łącyć, musza do siebie pasować jak elementy uktadanki. Trzeba dbać o każdy element, każdy rozwijać - wówczas cate miasto równomiernie i systematycznie się rozwija. Układaj z nami Giżycko!29

Miasto to trzydzieści tysięcy żywych organizmów $i$ samo jest jednym organizmem, ono żyje caly czas. Nie zasypia ani na chwile. Thumacze swoim pracownikom, że nasza praca $w$ urzędzie jest oceniana permanentnie, $24 h$ na dobę. Każde nasze potknięcie od razu widać, cokolwiek zrobimy niewtaściwie, nie na czas. Jedni potrzebuja ciszy, drudzy rozrywki. Pogodzenie ognia z woda. To jest misja ${ }^{30}$.

Miasto musi się rozwijać. Burmistrz podkreśla jego rozwój w ostatnich latach (infrastruktura miasta, wydarzenia kulturalne i sportowe, realizowane projekty ${ }^{31}$ ) i nazywa swoją kadencję czasem pozytywnych zmian. Nazywa miasto dziełem nieskończonym, co oznacza, że zawsze jest w nim coś do zrobienia i poprawienia.

W przestrzeni publicznej czy medialnej miasta wyraźnie widoczna jest aktywność jego mieszkańca - przedsiębiorcy budowlanego. Często wypowiada się na tematy publiczne, publikuje pogłębione analizy dotyczące różnych aspektów funkcjonowania miasta. Kandydował w wyborach

$28 \mathrm{Na}$ podstawie wypowiedzi burmistrza na profilu facebook: burmistrziwaszkiewicz.pl (7.04.2021).

$29 \mathrm{Na}$ podstawie wypowiedzi burmistrza na profilu facebook: burmistrziwaszkiewicz.pl (7.04.2021).

$30 \mathrm{Na}$ podstawie wypowiedzi burmistrza na profilu facebook: burmistrziwaszkiewicz.pl (7.04.2021).

$31 \mathrm{Na}$ podstawie wypowiedzi burmistrza na profilu facebook: burmistrziwaszkiewicz.pl (7.04.2021). 
do rady miasta w 2018 r., ale bez powodzenia. Przez pewien okres doradzał również społecznie burmistrzowi. Prowadzi na Facebooku specjalny profil poświęcony sprawom miejskim. Wypowiada się również na łamach lokalnej prasy.

Zwraca uwagę w swoich wypowiedziach na posunięcia lokalnych władz, ale jego wypowiedzi mają też szerszy, refleksyjny charakter, co dobrze oddaje tytuł jednego z artykułów: Poznać i zrozumieć miasto. Wskazuje na to, że władze miasta nie koncentrują się na sprawach ważnych: remonty chodników, tatanie dziur $w$ drogach czy sadzenie kwiatków na rondach to chyba najważniejsze sprawy polityki miejskiej. Wyraźnie widać, że drobne remonty urastaja do rangi spraw istotnych, wrecz priorytetowych. Liczy sie szybki efekt, ogłoszony sukces oraz chęć zaistnienia $w$ mediach spotecznościowych. Czasami mam wrażenie, że przekazywanie relacji z postępu prac budowlanych czy wydarzeń sportowych stało sie głównym zajęciem władz. Rządzenie stało się pewna gra, forma zabawy $i$ medialnym show.

Jednocześnie dostępna wiedza o mieście jest bardzo ograniczona, brakuje rozmyślań nad przyszłościa miasta. Na przykład trudno takiej poszerzonej wiedzy szukać w Raporcie o stanie miasta za rok 2018. Nie ma tam informacji o zmianach liczby ludności, wzroście zadłużenia miasta. Nie ma także informacji dotyczących turystyki, która uznawana jest przez władze miasta za główną gałąź gospodarki, brakuje podstawowych informacji o liczbie turystów, bazie noclegowej czy osiąganych z tego tytułu wpływach do kasy miasta.

Ten sam problem dotyczy potrzeb mieszkańców, ich oczekiwań $i$ subiektywnych odczuć mieszkańców dotyczacych jakości życia $w$ mieście. A są one nie mniej ważnej niż twarde dane. Nie istnieje wiedza na temat tego, jak mieszkańcy widzą możliwości własnego rozwoju zawodowego, czy są zadowoleni z opieki medycznej, systemu edukacji, jak spostrzegają swoją przyszłość? Jak mieszkańcy postrzegają przyszłość swoich dzieci - czy pragną, aby pozostawały one w mieście, czy też stwarzają im warunki do „ucieczki” i rozpoczęcia dorosłego życia poza miastem.

Mieszkaniec - przedsiębiorca budowlany operuje antynomią. Miasto jest pozycjonowane jako letnia stolica Polski, w rzeczywistości jednak jest coraz bardziej prowincjonalnym, wyludniającym się miastem średniej wielkości, które toczy walke o przetrwanie i utrzymanie swojej pozycji $w$ regionie.

Wymownym przykładem rozmijania się oczekiwań mieszkańców a polityką miejską był w 2019 r. spór o przyszłość budynku po dawnym kinie w centrum miasta wraz z przylegającym do niego terenem. Zderzają się tutaj dwie sprzeczne logiki myślenia. 
Władze miasta zamierzają ten obiekt i teren sprzedać prywatnemu inwestorowi i dzięki temu zlikwidować problem. Likwidowanie problemów polega na ich eksportowaniu poza obszar własnych kompetencji - wręcz ich wypchnięciu jak najdalej poza sfere samorzadowa. Taki problem znika z obszaru władz samorządowych, ale nie zostaje rozwiązany.

Dla wielu mieszkańców ten obiekt i teren jest natomiast najcenniejszym zasobem miasta - czymś niezbywalnym i nienaruszalnym. Chcą oni, aby ta przestrzeń pozostała wyłącznie do ich dyspozycji i była ogólnodostępna. Mógłby w tym miejscu powstać park lub nowy obiekt, który zaspokoi ich potrzeby kulturalne i tchnie życie w umierajace centrum miasta.

Wcześniej porównałem ze sobą dwa środowiska społeczne reprezentujące różne pokolenia mieszkańców miasta. Tutaj wracam do „Aktywnych”, bowiem to właśnie oni tworzą obecnie opozycyjny klub w radzie miasta, wspierają różnorakie inicjatywy społeczne, wypowiadają się ważnych dla miasta sprawach.

Stowarzyszenie zostało założone w 2013 r. i jest próbą zdefiniowania miasta $\mathrm{w}$ powiązaniu $\mathrm{z}$ aspiracjami i wartościami młodych mieszkańców. Jeden z liderów wskazuje na wprowadzanie nowych, cyfrowych mediów w przestrzeń miasta:

My byliśmy pierwsi, którzy wykorzystaliśmy w (mieście) facebooka. On tak jeszcze wtedy tak raczkowat. Wiesz, czujemy go i wykorzystaliśmy go. Kiedy jeszcze nikt nie wiedziat, jak go się obstuguje. My go rozwinęliśmy w sposób bardzo szybki. I te kanaty na YouTube, to wszystko. $Z$ takim świeżym podejściem i myślimy, że dlatego to tak opanowato. Bo jak masz facebooka to jest to częśc twojego życia, bo tak naprawde bez tego nie masz dnia. No, bo kto zakładat fanpage $w$ Giżycku wcześniej? Nie było takich. My byliśmy pierwsi.

[lider „Aktywnych”]

„Aktywni” byli też pierwsi w wielu innych kwestiach - pierwsi kręcili filmy promocyjne za pomocą drona (w 2014 r.), pierwsi robili sondy uliczne, pierwsi organizowali biegi charytatywne, nagrywali filmy o kontrowersyjnych tematach w życiu miasta na kanale YouTube. Osoby z pokolenia „Aktywnych” odkryły (jako pierwsze w mieście), że nowe technologie informatyczne mogą być niezwykle przydatne w realizowaniu rozmaitych przedsięwzięć, gdyż pozwalają na szybkie i skuteczne budowanie sieci społecznych. Powszechność dostępu do Internetu i marketingowe funkcje portali społecznościowych pozwoliły na szybsze i skuteczniejsze dotarcie do ludzi, również tych, którzy do tej pory nie byli aktywni w przestrzeni miejskiej. Przestrzeń miasta rozciagnęła się również na rzeczywistość 
wirtualną i od razu pojawiła się współzależność pomiędzy światem rzeczywistym a tym, co tworzyło się w realiach portali społecznościowych.

Pojawienie się przestrzeni wirtualnej zmieniło dotychczasowe rozumienie przestrzeni społecznej. Relacyjna przestrzeń społeczna co prawda definiuje przestrzeń w oderwaniu od danego terytorium - opisuje m.in. siłę relacji, ich współzależność i dynamikę, ale pojawienie się przestrzeni wirtualnej całkowicie „odrywa” przestrzeń od geografii ${ }^{32}$ (tworzy się niejako wirtualna wersja miasta). Tylko sam profil „Aktywnych” na facebooku ma ponad siedemnaście tysięcy polubień (miasto liczy ponad dwadzieścia siedem tysięcy mieszkańców) ${ }^{33}$.

Mechanizmy rządzące portalami społecznościowymi również zostały intuicyjnie odkryte przez twórców „Aktywnych”, ponieważ oni sami na podstawie własnych doświadczeń, odczuli potrzebę zachowania wirtualnego kontaktu z miastem. Jeden z liderów mówił w wywiadzie, że zanim wykrystalizował mu się w głowie pomysł na założenie stowarzyszenia i profilu facebookowego, myślał o stworzeniu strony internetowej, gdzie ludzie mogliby zamieszczać zdjęcia z rodzinnego miasta

Pomyst się wziąt stąd, że wyjechaliśmy na studia z bratem [...]. Masa była różnych forów miasta, różnych stron, gdzie mieszkańcy wrzucali zdjęcia. I jak wyjechatem z miasta na pierwszym roku studiów, $z$ tęsknota zagladatem, co tam ludzie wrzucaja, co sie zmienia. Czytatem sobie różne wpisy na forach, różne dyskusje, plany, krytykę władz. I mnóstwo byto tė̇ zdjeć. I pomyślatem, że już tyle jest tych miejsc, sa tak popularne, że fajnie bytoby to wszystko zgromadzić $w$ jednym miejscu, żeby każdy miał na wyciagnięcie ręki. I pomyślatem sobie, żeby założyć własna stronę miasta. Ale skoro już jest ich kilka, to jak się wypromuje swoja? I to byt taki zamyst, żeby skupić w jednym miejscu twórczość ludzi.

[lider „Aktywnych”]

"Aktywni” aktywizowali młodziez, ale nie tylko, hasłem przewodnim było coś więcej, przy czym chodziło o drobne rzeczy: post, pomoc wolontariacką, komentarz, zdjęcie, film, sondę uliczną, wywiad. Wydarzenia organizowane przez „Aktywnych” przybierały formy happeningów, akcji ulicznych, często o zabarwieniu politycznym, czasem bywały one prowokacyjne. Chodziło przede wszystkim o to, żeby wzbudzić ferment, pobudzić do reakcji - zarówno władze miasta, jak i zwykłych ludzi, zwłaszcza internautów, gdyż to właśnie w Internecie reakcja była największa i pojawiała się najszybciej, właściwie niemal natychmiast.

32 J. Van Dijk, Społeczne aspekty nowych mediów. Analiza społeczeństwa sieci, Warszawa 2010.

33 Stan na 25 stycznia $2020 \mathrm{r}$. 
Jak sobie pojechatem do Trójmiasta, pożyłem $w$ Gdańsku, w Gdyni, a potem do Warszawy, to zrozumiatem, że jest teraz masa możliwości tworzenia imprez, które sa $w$ dużych miastach, sq dzisiaj nawet powoli w Giżycku. One sa często praktycznie bezkosztowe. [...] I skoro my możemy mieć maraton $w$ Warszawie, to dlaczego nie możemy mieć maratonu $w$ naszym mieście?

[lider „Aktywnych”]

Działania $\mathrm{w}$ formie publicznych happeningów w połączeniu $\mathrm{z}$ promocją poprzez powszechnie użytkowany Internet sprawiły, że wydarzenia organizowane przez „Aktywnych” miały znacznie bardziej masowy charakter. Aktywizowały grupy dotychczas nieaktywne również dlatego, że formy albo treści zostały dopasowane do masowego odbiorcy. Często zapraszane osoby, formy, gatunki muzyczne, a także sama formuła wydarzeń pokrywała się z treścią kulturową znaną z najbardziej poczytnych gazet, portali internetowych, programów telewizyjnych. Były to zatem przede wszystkim publiczne imprezy sportowe, wydarzenia charytatywne, biegi, koncerty muzyki pop, spotkania ze znanymi politykami lub ludźmi rozrywki. Treści te lepiej korelowały z rzeczywistymi potrzebami masowego odbiorcy, niż muzyka jazzowa lub dyskusje naukowe dotyczące tożsamości mazurskiej (to było domeną wspomnianych już „Wspólnotowców”). Aktywizacja dotyczyła nie tylko biernego uczestnictwa, ale téz aktywnego współtworzenia - uczestnicy mogli mieć poczucie zaangażowania w dany projekt, choćby wypełniając ankietę w Internecie lub biorąc udział w dyskusji pod danym postem. Inkluzywność ta jest w dużej mierze spowodowana powszechnością dostępu do nowych technologii - tym, co Castells nazwał „przestrzenią przepływów” ${ }^{34}$. W dodatku zaangażować się w życie miasta można niezależnie od tego, czy aktualnie się w nim mieszka, czy nie.

Gdyby jeszcze raz porównać obecność „Wspólnotowców” z „Aktywnymi” w przestrzeni miasta, to również lokalizacja wydarzeń w przestrzeni miejskiej świadczy o odmiennym charakterze działań podejmowanych przez dwa stowarzyszenia stworzone przez różne pokolenia: „Wspólnotowcy” działali przeważnie „pod dachem” - w jazz clubie, w kawiarniach, na statku, w portach, w hotelach czy w galerii na stacji kolejowej. Ich przedsięwzięcia były często niewidoczne z zewnątrz, a co za tym idzie niedostępne, jeśli ktoś nie przeczytał ogłoszenia, nie został zaproszony.

Działania „Aktywnych” najczęściej odbywały się w miejscach publicznych - na ulicach, w parku, obiektach sportowych, na plaży miejskiej.

34 M. Castells, Społeczeństwo sieci, Warszawa 2007. 
Trudno było nie zauważyć, że coś się dzieje w przestrzeni miasta - przykład mogą stanowić biegi miejskie. Na trwale w krajobraz miasta wpisał się klub morsów zainicjowany przez członków stowarzyszenia. W sezonie jesienno-zimowym w każdą niedzielę o 12:00 niemal sto osób wchodzi do wody przy dźwiękach muzyki płynącej z dużych głośników, a wcześniej rozgrzewa się na plaży. Trudno o bardziej przykuwające wzrok wydarzenie, które w dodatku jest bardzo łatwo promować w Internecie, ponieważ generuje dziesiątki intrygujących, wesołych zdjęć i filmów, na których widać wielu ludzi.

Starsi mieszkańcy powitali aktywizację młodzieży pozytywnie:

$Z$ wielka radościa powitatem aktywność (...) z kilku przyczyn. W działalność - na poczatku przeważnie happeningowa, ale z wektorem prospołecznym, zaangażowało sie (...) wiele młodych osób, które dotychczas za bardzo nie uczestniczyly w życiu spotecznym miasteczka. Bardzo mi się podobata (i podoba) działalność (... - liderów), którzy - sami mtodzi - pociagnęli za soba wielu swoich rówieśników. Ten ruch wydawat sie jakąs takq ożywczq siła wobec wszystkich Uniwersytetów III Wieku i starzejących się (... - Wspólnotowców), nadzieja, że młodzi się obudzili i powoli zaczynaja brać sprawy $w$ swoje ręce.

[lider „Wspólnotowców”]

Pokolenie „Aktywnych” wzrastało w czasach, które z jednej strony cechowała euforia zmiany i nowej nadziei, a z drugiej strony ciężar trudnej transformacji, rekordowe bezrobocie lat dziewięćdziesiątych - szczególnie silnie odczuwane na prowincji, idąca za tymi zjawiskami wysoka przestępczość. Względny egalitaryzm epoki PRL-u, z ukształtowaną kulturalno-społeczną elitą miejską, do której zaliczali się m.in. dyrektorzy szkół i ośrodków sportowych, lekarze, nauczyciele, politycy, wojskowi - ustąpił pola szybkiemu wyłanianiu się nowej klasy średniej z grupą lokalnych biznesmenów, czyli osób, które potrafiły wykorzystać czasy transformacji, stać się jej beneficjentami. Panowało przeświadczenie o możliwości bardzo szybkiego wzbogacenia się, jeśli tylko miało się żyłkę do interesów. Wiele takich przykładów, również w badanym mieście, można podać. Niektóre ze stworzonych wówczas przedsiębiorstw, rodzice obecnie z dumą przekazują swoim dzieciom, odchodząc na emeryturę. W wielu jednak przypadkach emigracja młodego pokolenia sprawiła, że firmy nie ma komu przekazać. 
Jednocześnie budowało się (czasem iluzoryczne) przekonanie, że nowy system jest merytokratyczny, że jednostka - dzięki swoim talentom, wykształceniu i pracowitości - może osiagnać sukces ${ }^{35}$. W warunkach prowincjonalnego polskiego miasta bez uczelni wyższej, sukces można było najszybciej osiągnąć, wyjeżdżając. To mobilizowało młodzież do emigracji, w dodatku często była do tego zachęcana przez rodziców, którzy chcieli, żeby ich synowie i córki zdobyli możliwie najlepszą edukację. Po otwarciu granic i integracji z Unią Europejską, kierunkiem migracji często okazywała się nie Warszawa, Gdańsk czy Białystok, ale zagranica.

Skala tych wyjazdów w pewnym momencie była olbrzymia. Z wywiadów przeprowadzanych z absolwentami szkół i to niezależnie od rocznika wynika, że wyjechała większość osób ${ }^{36}$, czasem z całej klasy zostały w mieście dwie lub trzy osoby:

Wiesz co... Ja zawsze podchodze do tego w ten sposób. Licze osoby, które zostały w mieście. I tak, jak klasa liczyła te dwadzieścia kilka osób, a teraz mieszkaja tu może ze cztery osoby. Tak mi się wydaje, taki jest mój stan wiedzy. Bardzo mało. I w tej czwórce jestem ja, który wrócit tu (...) niedawno.

[mężczyzna, absolwent II LO, rocznik 1996]

Pojawia się pytanie, na ile osoby, które wyjechały, pozostały w przestrzeni społecznej miasta ${ }^{37}$. Są przecież członkami rodzin, ich rodzice mają nieruchomości, bądź firmy, a z czasem się starzeją i wymagają opieki ${ }^{38}$. Częśśc dzieci beneficjentów przemian żyjących na emigracji ogranicza pobyt w mieście do czasu świątecznego, kiedy przyjeżdżają odwiedzić rodzinę. Jest to dla nich także czas wzajemnych spotkań ze znajomymi, najczęściej w giżyckich lokalach gastronomicznych. Niektóre z tych osób to ludzie żyjący globalnie - zmieniający często prace i kraje, w których żyją, władający biegle co najmniej jednym językiem obcym.

35 J. Littler, Against Meritocracy. Culture, power and myths of mobility, Londyn i Nowy Jork 2017.

36 Sytuacja ta dotyczy szczególnie absolwentów liceów ogólnokształcących (obecnie w mieście działają dwa), w nieco mniejszym zakresie techników i szkół zawodowych.

37 Przypomnę, że wtedy gdy konsekwentnie mówimy o relacyjnej przestrzeni społecznej np. małego miasta, wówczas mogą do niej w różny sposób przynależeć aktorzy fizycznie ulokowani w dowolnym miejscu na kuli ziemskiej. Istotne jest pozostawanie w różnorakich relacjach z aktorami czy obiektami, którzy znajdują się w tym mieście fizycznie.

38 M. Budyta-Budzyńska, Emigracja powrotna - zyski i straty, kapitały i przekazy migracyjne. Na przyktadzie reemigracji z Islandii do Starych Juch, «CMR Working Papers» 2017, vol. 101/159. 
Wśród nielicznych, którzy wrócili do Giżycka po okresie nauki na wyższych uczelniach w Polsce, byli dwaj liderzy „Aktywnych”. Ponieważ jednak wyjechali niemal wszyscy, a wrócili tylko nieliczni - sieci społeczne zostały poważnie osłabione, a przestrzeń miasta zmieniona:

To byto na takiej zasadzie, że my wróciliśmy $i$ oprócz nas prawie nikt nie wrócit. I wtedy wtaśnie zaczą sie ten poważny kryzys, kiedy duży rocznik, z tego wyżu demograficznego lat osiemdziesiątych po prostu nie wrócit. I nagle byt duży problem. Bo przed studiami, przed wyjazdem chodziliśmy na różne turnieje pitki nożnej czy koszykówki, a po studiach byt pierwszy rok kiedy nic się nie odbyto. Żaden event, który nam od dziesiatego roku życia do osiemnastego zapewniat weekendy wakacyjne. Sezon się zamykat i naprawdę od września do maja byto 10\% ludzi.

[lider „Aktywnych”]

To doświadczenie powrotu do zmienionej rzeczywistości lokalnej wydaje się istotne przy próbie uchwycenia, jak definiuje miasto grupa skupiona wokół stowarzyszenia „Aktywnych”. Co prawda w wywiadach pojawiało się wielokrotnie stwierdzenie, że ludzie ci nigdy nie wyjechali z Giżycka i że stale utrzymywali kontakt z miastem, jednak spora grupa ich kolegów i koleżanek z klasy wyjechała na stałe i nie wróciła do miasta po ukończeniu studiów, a kontakt zachowują jedynie poprzez Internet i przyjazdy do domów rodzinnych na święta. Wydaje się, że migracja - obok Internetu - jest kluczem do zrozumienia tego pokolenia.

Ilu naszych kolegów $i$ koleżanek $z$ klasy maturalnej mieszka dalej (...)tutaj? W moim przypadku na trzydzieści dwie osoby, które uczyly się ze mna w II LO, w naszym mieście zostało pięcioro.

[lider „Aktywnych”]

Niektórzy z emigrantów to obecnie prawdziwi „obywatele świata”, realizujący swoje ambicje zawodowe i strategie życiowe praktycznie na całym świecie i żyjący globalnie. Najczęściej są to dzieci lokalnych elit, mające wyniesiony z domu duży kapitał kulturowy i wsparcie od rodziców w kluczowych momentach na drodze życiowej. W pewnym sensie realizacja ambicji rodziców obraca się przeciwko nim, bo często „tracą” dziecko, które na stałe żyje w Stanach Zjednoczonych, Australii bądź w Europie Zachodniej. Ci młodzi ludzie mają globalną perspektywę, co widać obserwując ich profile facebookowe, gdzie publikują zdjęcia z podróży oraz informacje o życiu zawodowym w wielkich, międzynarodowych korporacjach.

Co zatem charakteryzuje relacyjną przestrzeń społeczną w oczach „Aktywnych” i jak można przez pryzmat tej charakterystyki spojrzeć 
na miasto? Pokolenie, które weszło w dorosłe życie po akcesji Polski do Unii Europejskiej doświadczyło powszechności migracji w większym stopniu niż inne pokolenia. Zwiększona mobilność wypływała z samych cech pokolenia (indywidualizm, późniejsze zakładanie rodzin, dążenie do samorozwoju i osiągnięcia satysfakcji w życiu zawodowym). Zaadoptowanie nowych technologii spowodowało rozszerzenie relacyjnej przestrzeni miasta na rzeczywistość wirtualną i zachowanie codziennego kontaktu z miastem także przez osoby, które w nim na stałe nie mieszkają. Przedstawicielom pokolenia „Aktywnych” Internet służy do realizacji indywidualnych bądź zbiorowych projektów, w tym happeningów i eventów, które dzieją się zarówno w przestrzeni miejskiej, jak i wirtualnej - prawie zawsze jest to jednak przestrzeń publiczna, masowa. W odróżnieniu od poprzednich pokoleń, mniejsze znaczenie mają kwestie tożsamościowe, sentymentalne. Miasto w mniejszym stopniu jest zbiorem miejsc i obiektów o znaczeniu symbolicznym, w większym stopniu przestrzenią o pewnym potencjale, który można wykorzystać indywidualnie lub zbiorowo.

Miasto jest przez „Aktywnych” definiowane raczej przez rozliczne działania niż przez programowe czy refleksyjne wypowiedzi ich liderów czy aktywistów. I rekonstruuję tę definicję właśnie przez te działania. Składa się ona z dwóch elementów. Miasto, chociaż niewielkie, posiada potencjał, który może zaspokoić aspiracje młodych ludzi, odpowiadać ich wyobrażeniom o dobrym życiu i powstrzymać ich przez wyjazdem do większych ośrodków czy zagranicę. Obecnie miasto jest tworem składającym się co najmniej z czterech elementów, tworzących rodzaj figuracji czy nierozłącznego splotu. Są to mieszkańcy pozostający na stałe w mieście; mieszkańcy, którzy wyjechali z miasta i przebywają w kraju lub zagranica, ale nadal pozostają mieszkańcami ze względu na podtrzymywane i pielęgnowane powiązania z rodzinnym stronami; miasto składa się zarówno z przestrzeni fizycznej jak również przestrzeni wirtualnej.

Spróbuję odnieść te trzy „definicje” miasta do wymiaru politycznego, do tego, co polityczne. Są one raczej bardziej komplementarne wobec siebie niż tworzące przestrzeń rywalizacji i konfliktu. Są zatem bliższe wyobrażeniom Hannah Arendt o polityczności niż wyobrażeniom Carla Schmitta. Owszem, tworzą one przestrzeń możliwej i dokonującej się rywalizacji. „Aktywni” tworzą przecież opozycyjny wobec burmistrza i jego ugrupowania klub w radzie miasta. Przedsiębiorca kandydował z listy „Aktywnych” do rady. Jednak też podjął współpracę z burmistrzem jako jego społeczny doradca. Współpraca ta się jednak, po pewnym czasie, zakończyła. 
Kluczowa zatem w tym, co polityczne w małym mieście jest relacja między polem współpracy a polem rywalizacji. Można śmiało powiedzieć, że jest to generalnie kluczowa kwestia dla tego, co polityczne. Jedno i drugie tworzy sferę polityczności.

Widać również, że sami aktorzy współtworzący tę sferę w małym mieście nie zdają sobie z tego w pełni sprawy. W tym kontekście można spojrzeć na etnografię wielostanowiskową jako rodzaj pomostu między naukową refleksją (tutaj analizowaniem polityczności) a kompetencjami działających w badanej przestrzeni aktorów.

Gdy patrzymy na rzeczywistość w kategoriach ekologicznych dostrzeżemy, że małe miasto to system współzależnych od siebie elementów, a działający w nim aktorzy dążą przede wszystkim do utrzymywania posiadanych zasobów. W świetle powyższych rozważań do „gatunków inwazyjnych” można byłoby zaliczyć partie polityczne, które przynajmniej w polskich realiach swój byt opierają na rywalizacji i polaryzacji.

$\mathrm{Na}$ system ekologiczny małego miasta składa się, oczywiście, wiele innych elementów. I wymagają one pogłębionej analizy. Tutaj chciałem jedynie wskazać, że etnografia wielostanowiskowa czyni świat małego miasta bardziej dostępnym poznawczo, i co nie mniej ważne, otwiera nas na poszukiwania teoretyczne i ich ściślejsze, bardziej wszechstronne powiązanie z badaną rzeczywistością, szukanie równowagi między wnioskowaniem indukcyjnym i dedukcyjnym.

\section{Podsumowanie}

Kilka lat temu pisałem $\mathrm{w}$ artykule pomieszczonym w tomie Politologia 2.039, że na wyzwania stojące przed naukami społecznymi w Polsce, w tym nauki o polityce, można spojrzeć z co najmniej kilku perspektyw. Ten artykuł jest swego rodzaju uszczegółowieniem formułowanych tam postulatów.

Zawarłem w nim polemikę z boomem na określony model politologii (dotyczy to również socjologii w tym socjologii polityki) - jako nauki „twardej”, opartej na precyzyjnych pomiarach, ujmującej rzeczywistość polityczną za pomocą złożonych narzędzi opartych na statystyce, doborze prób. Innymi słowy, za naukowe miałoby uchodzić w zasadzie tylko to, co

39 W. Łukowski, Nauki o polityce w Polsce - zależność od szlaku i syndrom spóźnionego przybysza, [w:] S. Sulowski (red.), Nauki o polityce 2.0. Kontrowersje i konfrontacje, Warszawa 2018, s. 201-220. 
przynosi pewne, empirycznie potwierdzone wyniki w sondażowym, czy - szerzej - statystycznym pomiarze. Nieśmiało zwracano uwagę na to, że wypracowane metody, koncepcje teoretyczne sprawdzają się głównie w stabilnych, spokojniejszych czasach. Są skuteczne wtedy, gdy opierają się na założeniach odnoszących się do rzeczywistości, która, przy całej swojej zmienności, reprodukuje się w swojej podstawowej konstrukcji. Natomiast nie zajmuje się tym, co polityczne (das Politische) w znaczeniu poszukiwania głębszych, często ukrytych uwarunkowań politycznej rywalizacji i kooperacji.

Etnografia wielostanowiskowa przyjmuje zmienność społecznego świata, przyspieszenie wielu procesów i czasu społecznego za punkt wyjścia. Jest też rodzajem reakcji na tą zmienność.

Zimą 2020 r. na globalnej scenie społecznej pojawił się nowy „aktor”. Stał się zagrożeniem dla ładu światowego, stał się śmiertelnym zagrożeniem dla każdego z nas. Utrudnił bądź pokrzyżował dotychczasowe plany badawcze lub znacznie utrudnił ich realizację. Dokonał też - jak sadzę - swego rodzaju aktualizacji etnografii wielostanowiskowej jako użytecznego „oprogramowania” do badania złożonych, dynamicznych systemów społecznych, w których intencjonalność działań w jeszcze większym stopniu wywołuje nieprzewidziane skutki, tworząc w ten sposób nowe stanowiska badawcze.

\section{Bibliografia}

Beck U., Społeczeństwo ryzyka. W drodze do innej rzeczywistości, Warszawa 2002.

Bourdieu P., Wacquant L.J.D., Zaproszenie do socjologii refleksyjnej, Warszawa 2001.

Bröckling U., Feustel R., Einleitung, Das Politische denken, [w:] U. Bröckling, R. Feustel (red.), Das Politische denken. Zeitgenossische Positionen, Bielefeld: Transit Verlag, 2012.

Budyta-Budzyńska M., Emigracja powrotna - zyski i straty, kapitały i przekazy migracyjne. Na przykładzie reemigracji z Islandii do Starych Juch, «CMR Working Papers» vol. 101/159.

Castells M., Społeczeństwo sieci, Warszawa 2007.

Geertz C., Interpretacje kultur, Kraków 2005.

Heffner K., z Uniwersytetu Ekonomicznego w Katowicach, podczas wykładu „Czy jest przyszłość dla małych miast w Polsce?”, Uniwersytet Warszawski, 7.11.2019 r.

Heffner K., Marszał T., Małe miasta - studium przypadków, Łódź 2005.

Hess S., Schwertl M., Vom „Feld“ zum „Assemblage“? Perspektiven europäisch-ethnologischer Methodenentwicklung - eine Hinleitung, [w:] S. Hess, J. Moser, M. Schwert (red.), Perspektiven etnhologisches Forschen. Neue Methoden und Konzepte, Berlin 2012.

Hobfoll S.E., Stres, kultura i społeczność. Psychologia i filozofia stresu, Gdańsk 2006.

Hobsbawm E., Ranger T., (red.), Tradycja wynaleziona, Kraków 2008.

Latour B., Das Parlament der Dinge. Für eine politische Ökologie, Frankfurt nad Menem 2011. Levi-Strauss C., Smutek Tropików, Warszawa 1964.

Littler J., Against Meritocracy. Culture, power and myths of mobility, Londyn i Nowy Jork 2017. 
Łukowski W., Nauki o polityce w Polsce - zależność od szlaku i syndrom spóźnionego przybysza, [w:] S. Sulowski (red.), Nauki o polityce 2.0. Kontrowersje i konfrontacje, Warszawa 2018. Marcus G., Ethnography through Thick and Thin, Princeton 1998.

Matsutake Worlds Research GroupStrong Collaboration as a Method for Multi-sited Ethnography: On Mycorrhizal Relations, [w:] M-A. Falzon (red.), Multi-sited Ethnography. Theory, Praxis and Locality in Contemporary Research, Routledge 2009.

Piore M.L., Birds of Passage: Migrant Labor and Industrial Societies, Cambrigde 1979.

Reckwitz A., Die Gesellschaft der Singularitäten, Frankfurt am Main 2016.

Reckwitz A., Die Gesellschaft der Singularitäten, Frankfurt nad Menem 2017.

Szukalski P., Solidarność pokoleń. Dylematy relacji międzypokoleniowych, Łódź 2012.

Van Dijk J., Społeczne aspekty nowych mediów. Analiza społeczeństwa sieci, Warszawa 2010.

Wesołowski W., Janicka K., Słomczyński K., Strukturalizacja społeczeństwa polskiego. Ewolucja paradygmatu, Warszawa 2017. 